This manuscript is a non-peer reviewed preprint submitted to EarthArXiv that is currently undergoing peer-review in Geosphere.

Future versions of this manuscript may therefore have different content.

Feedback is very welcome. Please contact corresponding author Euan Soutter

(euan.soutter@manchester.ac.uk) if you have any comments. 


\section{Controls on submarine canyon connection to the shoreline: a numerical modelling approach}

2 Euan L. Soutter ${ }^{1}$, Ian A. Kane ${ }^{1}$, David M. Hodgson², Stephen Flint ${ }^{1}$

3 1Department of Earth and Environmental Science, University of Manchester, Manchester, M13 9PL, United

4 Kingdom

$5 \quad{ }^{2}$ School of Earth and Environment, University of Leeds, Leeds, LS2 9JT, United Kingdom

6 Correspondence to: Euan L. Soutter (euan.soutter@manchester.ac.uk)

7

\section{Abstract}

9 Submarine canyons with heads located close to shorelines, known as shore-connected canyons, provide a focussed

10 pathway for basinward sediment transport. Placing greater constraints on the key parameters that control the formation

11 of shore-connected canyons can help us predict the efficiency of sediment export to deep-water under different

12 environmental conditions and through time. Using a numerical model incorporating geomorphic principles, we show

13 that shore-connected canyons are most active when fluvial discharge is high, the continental shelf is steep and narrow,

14 and the magnitude of relative sea-level change is high. The numerical model reproduces observed bathymetric

15 distributions of shore-connected submarine canyons, indicating that the empirical relationships underlying these

16 numerical models are accurate descriptions of shore-connected canyon formation in nature. Our study provides

17 constraints on the key quantifiable parameters controlling shore-connected submarine canyon formation and

18 maintenance, such as fluvial discharge and basin physiography, allowing for more accurate predictions of the efficiency

19 and timing of sediment transfer to the deep sea under different conditions. The model results suggest that; 1) submarine

20 canyons may form frequently on the slope due to submarine processes, but subaerial processes control which submarine

21 canyons are most likely to connect to the shoreline, 2) margin physiography and sediment supply are more influential

22 in driving submarine canyon incision across the shelf and sediment transfer than the exact nature of the gravity flow 
23 triggering mechanism, and 3) the stratigraphic records of shore-connected submarine canyons and fans are more

24 influenced by onshore climate and tectonics than eustasy.

\section{1. Introduction}

26 Submarine canyons are erosional conduits found globally on continental margins, and act as focal points for the transfer

27 of terrigenous sediment from shallow to deep water (Fig. 1A) (e.g. Buchanan, 1887; Daly, 1936; Shepard, 1981; Harris

28 and Whiteway, 2011; Puig et al., 2014; Fisher et al., 2021). Submarine canyons evolve through a combination of: 1)

29 erosion by submarine gravity flows, often initiated by hyperpycnal flows from river mouths or failure of accumulated

30 sediment near the canyon head, 2) erosion by rivers during subaerial exposure of the shelf, and 3) retrogressive erosion

31 by canyon-wall failure (e.g. Farre, 1983; Pratson et al., 1994; Pratson and Coakley, 1996; Mountjoy et al., 2009; Allin et

32 al., 2018). Therefore, many submarine canyons are incised across the continental shelf and connect directly to rivers

33 and shorelines (Fig. 1A) (e.g. Khripounoff et al., 2009; Harris and Whiteway, 2011; Huang et al., 2014; Maier et al.,

34 2018).

36 The distance between the canyon head and the shoreline plays a critical role in determining the calibre of sediment

37 transported through the canyon, with analysis of Quaternary canyons revealing that the canyon head must come within

$385 \mathrm{~km}$ of the shoreline in order to transfer sand-grade sediment to deeper water (Sweet and Blum, 2018). The prevalence

39 of shore-connected canyons along continental margins is therefore a fundamental control on the transport efficacy of

40 terrigenous sediment, organic matter, and pollutants, to submarine environments. Shore-connected canyons can form

41 tsunami hazards for coastal communities via failure of the canyon walls (Casalbore et al., 2018), therefore, better

42 constraints on the processes controlling canyon connection to the shoreline have implications for societal and

43 infrastructure resilience. 


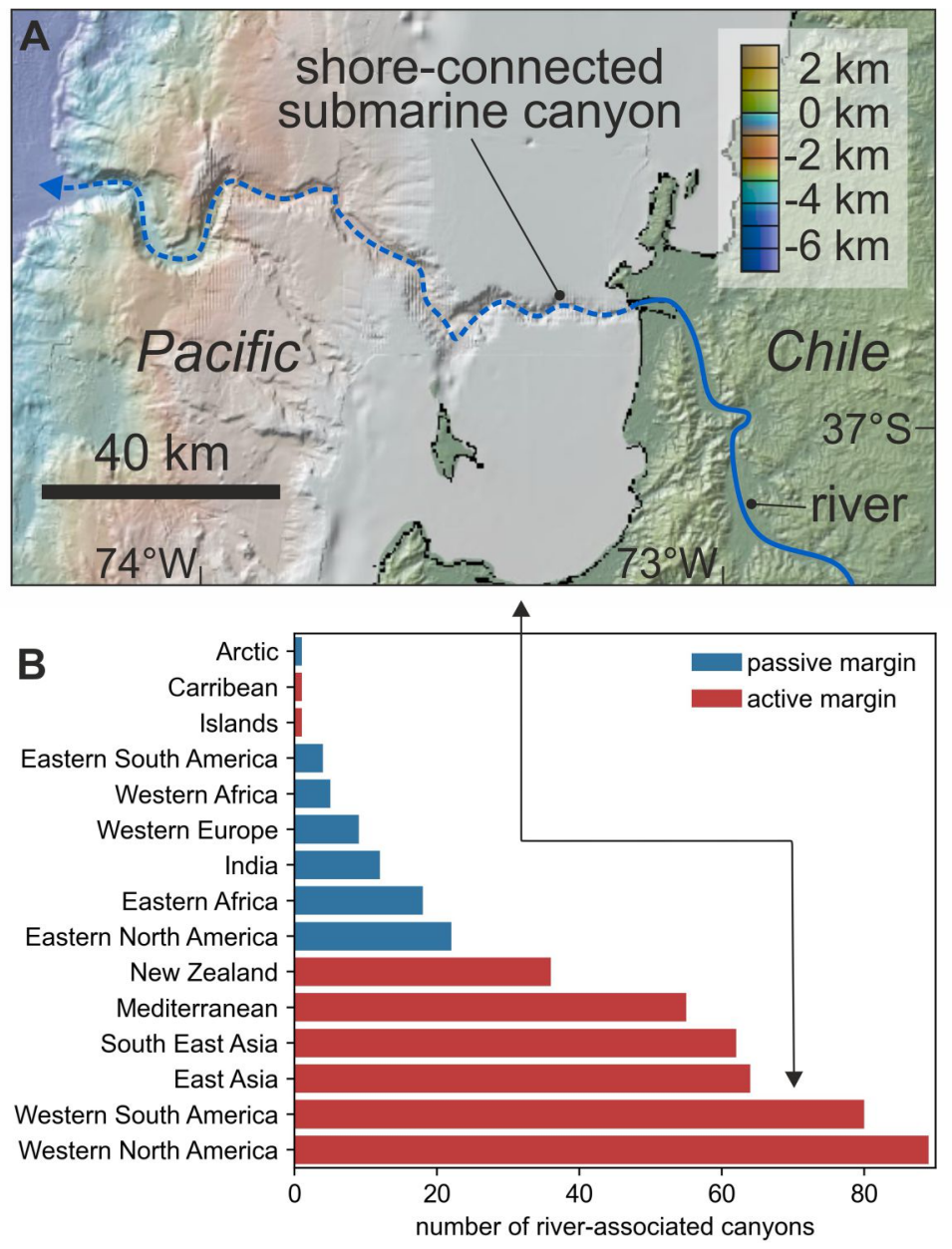

45 Three key factors have been suggested to increase the prevalence of shore-connected canyons; 1) narrow shelves, 2)

46 high supply of coarse-grained sediment, and 3) high magnitude relative sea-level change (Harris and Whiteway, 2011;

47 Sweet and Blum, 2018; Smith et al., 2017; 2018). This is supported by analysis of present-day canyons, with canyons

48 formed on narrow shelves, steep shelves, and subject to high subaerial discharge from relatively unerodible bedrock

49 hinterlands more likely to remain connected to the shoreline (Bernhardt and Schwanghart, 2021), which is also reflected

50 in the prevalence of river-associated canyons on active margins characterised by these factors (Fig. 1B) (Harris and

51 Whiteway, 2011). The observed correlation between slope, discharge and submarine canyon erosion implies that

52 submarine canyon formation may be described through heuristic geomorphic principles commonly applied to rivers,

53 such as the stream power law (e.g. Whipple and Tucker, 1999; Braun and Willet, 2013). The stream power law describes 
54 vertical incision of river channels into bedrock as a function of channel slope and discharge, and has been used

55 extensively in numerical modelling of landscape and stratigraphic evolution (e.g. Ding et al, 2019; Zhang et al. 2020).

56 Modifications of the stream-power law for the purpose of modelling submarine canyon erosion has been applied

57 previously by Petit et al. (2015), who reconstructed canyon evolution in the NW Mediterranean, and by Thran et al.

58 (2020), who showed how carbonate mounds control submarine erosion and canyonisation in the Great Barrier Reef.

60 In order to assess whether these geomorphic principles can replicate the observed distributions of shore-connected

61 submarine canyons, we aim to generalise these more targeted case-studies within a synthetic continental margin. If

62 replicable, then these principles may be more confidently applied to 1) model periods of geological time where canyon

63 distribution cannot be directly measured, thus providing insights into the efficacy of sediment transport to deeper-water

64 during past and future tectonic and climatic conditions, and 2) predict the rate at which present-day canyons may incise

65 across the shelf, thus increasing the accuracy of coastal hazard forecasting and anthropogenic pollutant transport to the

66 deep ocean.

\section{2. Model}

\section{2.1 Description}

69 This study utilises the open-source pyBadlands modelling package (Salles et al., 2018), which allows simulation of both

70 subaerial and submarine erosional and depositional processes. Subaerial fluvial erosion $(\dot{\boldsymbol{\varepsilon}})$ is described by a detachment-

71 limited stream power law (e.g. Braun and Willett, 2013):

$$
\dot{\varepsilon}=-k_{d} A^{m} S^{n}
$$

73 where $k_{d}$ is a dimensional coefficient describing erodibility of the channel bed, $A$ is drainage area (a proxy for discharge

74 and function of precipitation), $S$ is local slope, and $m$ and $n$ are dimensionless positive constants (Salles et al., 2018). 
75 Submarine erosion corresponds to a hyperpycnal submarine extension of the subaerial fluvial network, with $A$ restricted

76 to the subaerial drainage extent, and $S$ modified to $S_{\text {eff }}$ (Petit et al., 2015; Thran et al., 2020):

$$
S_{\text {eff }}=S \frac{\rho_{s-} \rho_{w}}{\rho_{s}}
$$

78 where $\rho_{s}$ is the sediment density and $\rho_{w}$ is the water density. Submarine erosion and entrainment by turbidity currents

79 is initiated when the sediment-water mixture within the hyperpycnal flow network reaches a pre-defined critical density

$80\left(1000.04 \mathrm{~kg} / \mathrm{m}^{3}\right)$. The critical density is required to be low as the model is unable to episodically trigger turbidity

81 currents, therefore erosion by turbidity currents is modeled over longer timescales (Thran et al., 2020). Deposition $\left(d_{p r o p}\right)$

82 from turbidity currents occurs as a function of the local slope and a dimensionless scaling parameter $(\alpha)$ (Lowe, 1976):

$$
d_{\text {prop }}=\frac{0.9}{1+e^{\propto(S-0.005) \prime}}
$$

84 This numerical description of turbidity current erosion and deposition has been used successfully to recreate the 85 geomorphic evolution of canyons on the Great Barrier Reef slope, Australia (Thran et al. 2020). Creep and slope failure 86 are accounted for in the model by a linear diffusion law (e.g. Sweeney et al., 2015):

$$
\frac{d z}{d t}=k_{h l} \nabla^{2} z
$$

88 where $z$ is topographic elevation and $k_{b l i s}$ a diffusion coefficient with different values for subaerial (Martin and Church, 89 1997) and submarine (Fagherazzi et al., 2004) environments (Supplementary Table 1). Instantaneous slope failure is

90 accounted for by increasing $k_{b l}$ when a pre-defined critical slope threshold is reached $\left(>10^{\circ}\right)$. Compaction is accounted

91 for by a negative exponential function (Athy et al., 1930), assuming a surface porosity of $42 \%$ (Beard and Weyl, 1973).

92 Wave-induced longshore drift is modelled according to linear wave theory (see Salles et al. 2018 for full numerical

93 description), with the wave-field in these experiments orientated oblique to the coast (coming from the SE). Waves 
94 entrain and transport sediment parallel to their breaking point once a critical shear stress at the seabed has been reached.

95 Once the critical shear stress drops below the threshold, or the seabed depth drops below the maximum wave base (set

96 at $20 \mathrm{~m}$ ), deposition occurs (Thran et al. 2020).

\subsection{Configuration}

98 The initial model configuration represents a generic continental margin (e.g. Harris et al., 2014) (Supplementary Fig. 1),

99 with a source area supplying sediment to a $0.01^{\circ}$ dipping fluvial transfer zone that terminates at sea-level (Fig. 2A). In

100 order to test the influence of sediment supply on canyon formation, the source area was split into two segments, with

101 the lower (southern) segment $(0-150 \mathrm{~km})$ having an initial slope angle of $0.1^{\circ}$ and uplifting at $500 \mathrm{~m} / \mathrm{myr}$, representing

102 a higher-supply source, and the upper (northern) segment $(150-300 \mathrm{~km})$ having an initial slope angle of $0.05^{\circ}$ and not

103 uplifting, representing a lower-supply source. Erosion was not measured within a transition zone between the two

104 segments $(125-175 \mathrm{~km})$ in order to fully isolate the impact of sediment supply on canyon distribution. Below sea-

105 level, the model comprises a shelf and a slope separated by a well-defined gradient change, with the slope logarithmically

106 decreasing from $\sim 4^{\circ}$ at the shelf-break to horizontal on the basin floor (Fig. 2A). Each component of the subaerial and

107 submarine margin is $300 \mathrm{~km}$ in length (Y-direction, or depositional strike), with the source area, and transfer zone held 
at constant planform width of $50 \mathrm{~km}$ (X-direction, or depositional dip). In order to maintain a $300 \times 300 \mathrm{~km}$ grid, the

109 slope width varies from 150 to $200 \mathrm{~km}$ as the shelf width is varied (Fig. 2A).

111 Three groups of models were designed based on this initial configuration, with two of these groups varying a different

112 shelf property six times (Fig. 2B). The first group tested the effect of shelf width on canyon connection $(0-50 \mathrm{~km}$ in

$11310 \mathrm{~km}$ increments), and the second group tested the effect of shelf angle on canyon connection $\left(0.01-0.5^{\circ}\right.$ in $0.1^{\circ}$

114 increments) (Fig. 2B). Sea-level is varied through a sinusoidal sea-level curve, which drops to minimum of $-60 \mathrm{~m}$ and

115 repeats for five 100 (eccentricity) kyr cycles. The third group of models varied the magnitude of sea-level change from

116 no sea-level change, to $-15 \mathrm{~m},-30 \mathrm{~m},-60 \mathrm{~m},-120 \mathrm{~m}$ and $-240 \mathrm{~m}$ change, with the lower-magnitude changes $(0$ to -30
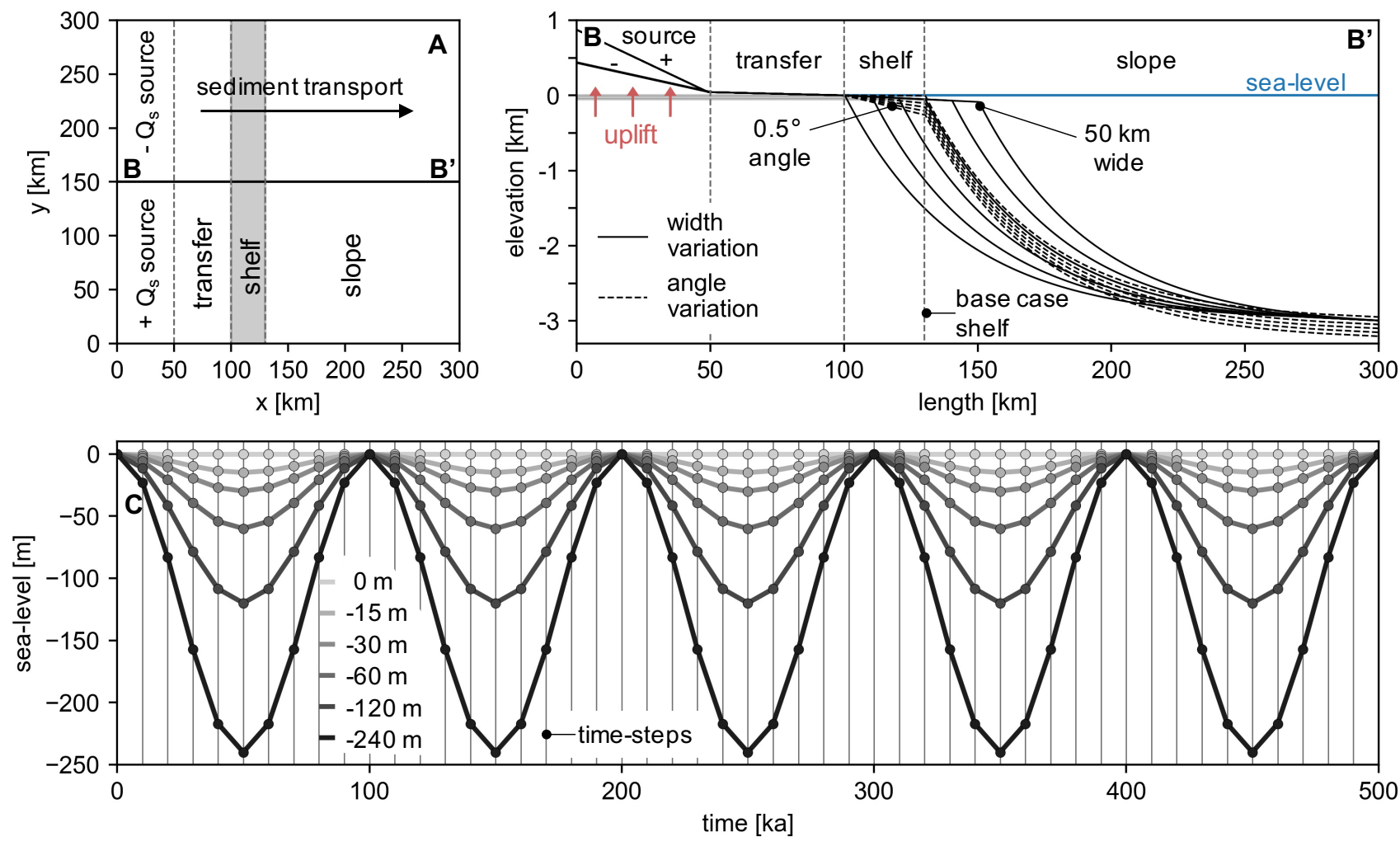

$117 \mathrm{~m}$ ) approximating greenhouse eustasy, and the higher-magnitude changes (-60 to $-120 \mathrm{~m}$ ) approximating icehouse

118 eustasy (Miller et al. 2020), and relative sea-level change caused by tectonics (-240 m). Shelf angle and sea-level were 
119 varied for a $30 \mathrm{~km}$ wide shelf and $0.1^{\circ}$ dipping shelf, and each group of models ran for a period of $500 \mathrm{kyr}$,

120 approximating five $100 \mathrm{kyr}$ (eccentricity) cycles, at a time-step of $10 \mathrm{kyr}$. Reconstructed sea-level curves, such as those

121 from the Quaternary, were not used in order to more fully control and isolate the influence of sea-level change.

122 Results are presented as: 1) maps of positive (deposition) and negative (erosion) elevation at model end, and 2) shore

123 erosion through time in both the high supply and low supply segments of the margin (Fig. 3, 4, 5). The shore is defined

124 as the median sea-level position plus a horizontal distance of $5 \mathrm{~km}$, assuming that canyons that do not intersect this

125 zone are much less able to transport sand-grade sediment down-slope (Sweet and Blum, 2018). In order to calculate

126 the percentage of time canyons are connected to the shore (Fig. 6), canyon connection is inferred to occur when erosion

127 in this zone meets a cut-off of $0.05 \mathrm{~km}^{3} / \mathrm{yr}$ (Fig. 3, 4, 5).

\section{$128 \quad 2.3$ Limitations}

129 These models assume that the dominant force driving shore-connected canyon formation is erosion by hyperpycnal

130 flows. Other factors known to control canyon formation, such as erosion beneath remobilised sediments (e.g. Puig et

131 al. 2014), are not captured. This is less important for river-connected canyons, because any slope failures that occur

132 from sediment accumulated at river mouths are likely to flow in the same general direction as the river that fed them,

133 but later. This limitation may affect the incision of canyons connected by littoral currents instead of rivers directly,

134 however, because the accumulated sediment could have been transported significant distances from the river mouth.

135 Similarly, these models do not capture erosion beneath gravity flows derived from canyon-wall failure (e.g. Micallef et 136 al. 2012), or erosion beneath more regional and unconfined gravity flows, such as dense shelf water (Puig et al. 2008,

137 Canals et al., 2006). These factors will all act to increase the number of canyons present on the slope and increase the

138 rate of canyon head propagation across the shelf, therefore the model outputs are likely more representative of erosive

139 trends as opposed to absolute erosion rates. 
141 In all models, uplift of the source area results in subaerial erosion and marine deposition (Fig. 3, 4, 5). Once sediment

142 reaches the marine environment it is either: 1) deposited and stored on the shelf, 2) deposited on the shelf and

143 remobilised along- or down-slope by mass-movements or wave currents, or 3) bypassed across the shelf entirely and

144 deposited beyond the shelf-break by turbidity currents. Deposition below the shelf-break is concentrated where slope

145 angle drops below $\sim 0.5^{\circ}$ (Fig. 3, 4, 5). Submarine erosion occurs in all the models to varying degrees, with increased

146 submarine erosion always correlated with increased deposition in submarine fans on the lower slope and basin floor,

147 and decreased deposition in deltas on the shelf, i.e., sediment bypass to deeper water is positively correlated with

148 submarine canyon erosion. Deposition in submarine canyons occurs due to submarine fan aggradation at the canyon-

149 mouth. This aggradation increases the relief of the fan, which eventually results in back-filling of the submarine canyon

150 as turbidity currents are progressively forced to deposit against the upstream facing slope of older deposits. Avulsion

151 is inhibited by the canyon confinement, so back-filling tends to occur quickly once the canyon-mouth is choked.

153 When the shelf width is varied, slope canyon prevalence and shore erosion increase with decreasing shelf width. Coastal 154 erosion is greatest on the high supply side of the model and during the fastest rate of sea-level fall in all cases. When 155 no shelf is present, shore erosion continues to increase as sediment supply increases, resulting in canyons remaining 156 connected to shoreline irrespective of the sea-level change. With the addition of a shelf, shore erosion drops to almost 157 zero during highstand, but the drop occurs from a higher erosion rate when the shelf is narrower. Canyon connection 158 therefore only occurs during lowstands, and at increasingly short durations of the lowstand as the shelf width increases.

160 When shelf angle is varied, canyons generally become more numerous and incise deeper into the slope as the shelf 161 steepens. An exception to this trend occurs when the shelf is almost horizontal, and numerous canyons form on the 162 slope. These canyons do not extend far down the slope, however. Shore erosion shows a more complicated pattern, 
163 with erosion being greatest when the shelf is shallowest and when the shelf is steepest, and little erosion occurs between

164 these end-member points. Shore erosion is therefore somewhat decoupled from slope canyon prevalence, i.e., when

165 the shelf is steep, coastal erosion is more similar to the models with wide shelves, even though slope canyons are much

166 more prevalent when the shelf is steep. Shore erosion and canyon prevalence is again reduced on the low-supply side

167 of the model, although the trend of erosion through time is similar. Interestingly, shore erosion reaches a maximum

168 when sea-levels are highest as the shelf angle increases.

170 When the magnitude and rate of sea-level change is varied, both slope canyon prevalence and shore erosion increases

171 with increasing sea-level change., with the fastest rates of shore erosion associated with the fastest rates of sea-level fall.

172 No shore erosion occurs with low-magnitudes of sea-level change (0 to $-30 \mathrm{~m})$, and the maximum coastal erosion

173 recorded across the models occurs when the sea-level change is greatest $(-240 \mathrm{~m})$. A sea-level fall of $120 \mathrm{~m}$ produces

174 similar erosional patterns as a $60 \mathrm{~m}$ sea-level fall on a narrow shelf. The evolution of shore erosion follows a similar

175 pattern to that described previously; reaching a maximum when the rate of sea-level fall is fastest before rapidly

176 decreasing to almost no erosion as the sea-level rises. This is the same on both low and high supply sides of the model,

177 however canyon prevalence is reduced on the low-supply side, as seen in the other models.

\section{4. Discussion}

\section{Controls on shore-connected canyon formation}

181 These results show that shore-connected submarine canyons are most likely to form when; 1) shelves are narrow, 2)

182 shelves are steep, 3) sediment supply is high, and 4) the magnitude of sea-level change is high. This is in agreement with 183 observations from the Quaternary shore-connected canyons (Sweet and Blum, 2018; Bernhardt and Schwanghart, 184 2021), indicating that the physical principles underlying these models reflect shore-connected canyon evolution in the 185 natural world. Since gravity flow triggering mechanisms are simplified in these models, this indicates that sediment 186 supply and basin physiography are more important controls on submarine connection to the shoreline than the exact 
187 triggering mechanism, e.g., hyperpycnal flows or delta-front failure, over millennial timescales. In other words, the

188 frequency of gravity flow generation and the slope over which these flows travel are the dominant controls on

189 submarine canyon incision, and both of these are best predicted by sediment supply and basin physiography. This also

190 implies that while submarine canyons may form frequently on the slope through submarine processes, the conditions

191 required for certain canyons to incise across the shelf are dictated by onshore processes.

193 Narrow shelves increase shore-connected canyon prevalence by increasing the likelihood of gravity flows bypassing the

194 shelf and reaching the higher gradient slope before they dissipate by deposition and dilution, forming mouth bars (e.g.

195 Melstrom and Birgenheier, 2021), highstand shelf fans (Steel et al., 2006), or more current-modified depositional bodies,

196 such as spits (e.g. Nienhuis et al., 2016) (Fig. 7). Similarly, steep shelves increase the prevalence of submarine canyons

197 by increasing the erosive potential of gravity flows. This is mediated by the increased accommodation associated with

198 higher shelf angles, however, which allows for sediment to accumulate between adjacent rivers and between rivers and

199 the shelf-break, thus shallowing the shelf gradient (Fig. 7).

201 High magnitude sea-level falls influence coastal erosion by increasing the duration of fluvial erosion on the shelf,

202 forming incised valleys that are later exploited by submarine flows, forming deeper submarine canyons in a feedback

203 loop (Fig. 7). Sea-level fall also increases shore-connected canyon prevalence by perching river mouths on the steep

204 continental slope during lowstand, thus increasing the erosive potential of the hyperpycnal flows they produce (Fig. 7),

205 and the erosive potential of flows derived from failure of accumulated sediment. If the shelf is wide these canyons are

206 then mostly abandoned when the sea-level rises (Fig. 6).

208 All of these canyon-forming processes are enhanced when discharge is high enough to generate frequent hyperpycnal 209 flows (e.g. Petit et al. 2015) or rapidly aggrade sediment to the point of failure and gravity flow generation. This is 210 supported by observations from modern systems, which indicate that high discharge and supply of coarse-grained, 
211 unerodible sediment predict shore-connected canyon formation (Smith et al. 2017; 2018; Bernhardt and Schwanghart, 212 2021). 

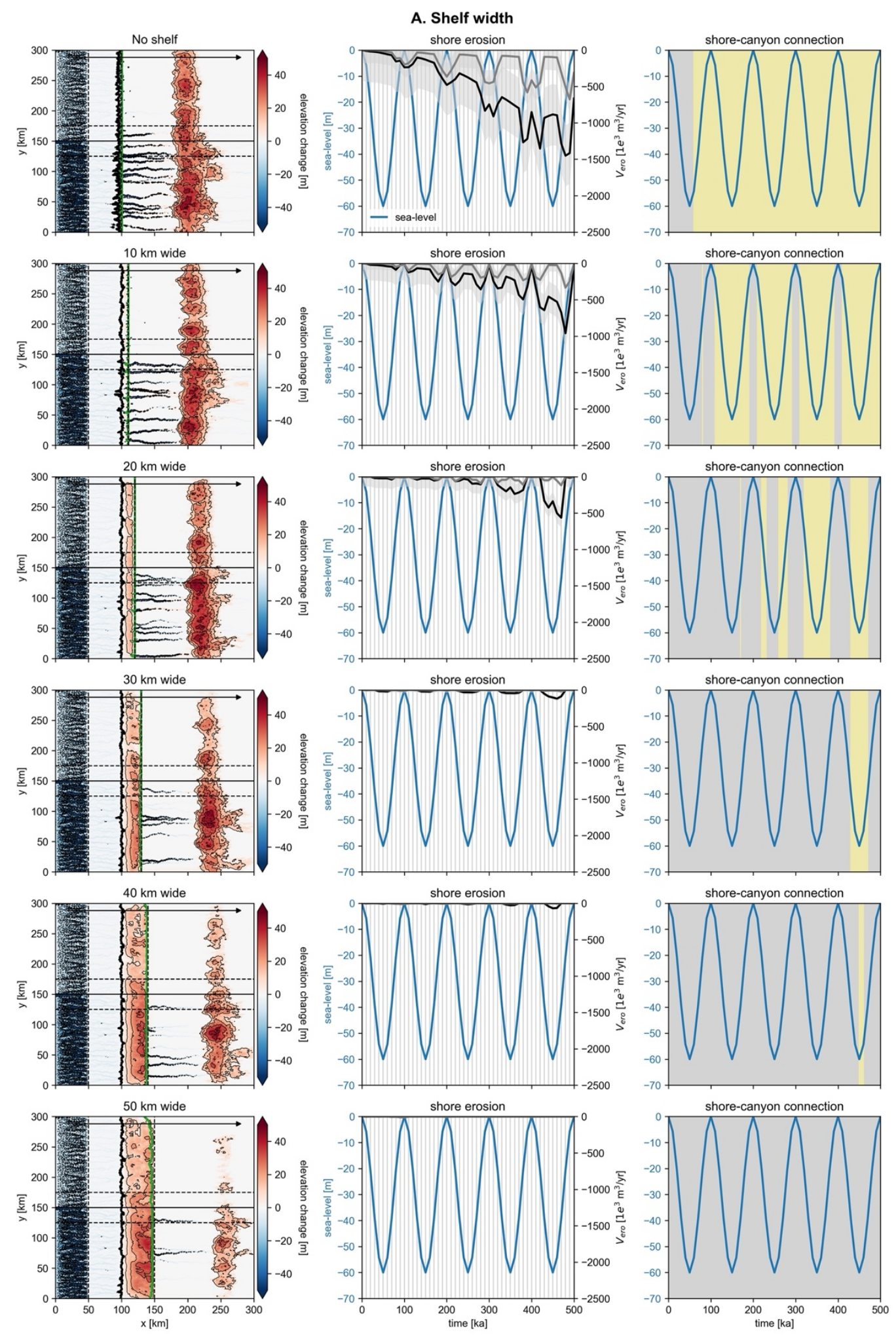

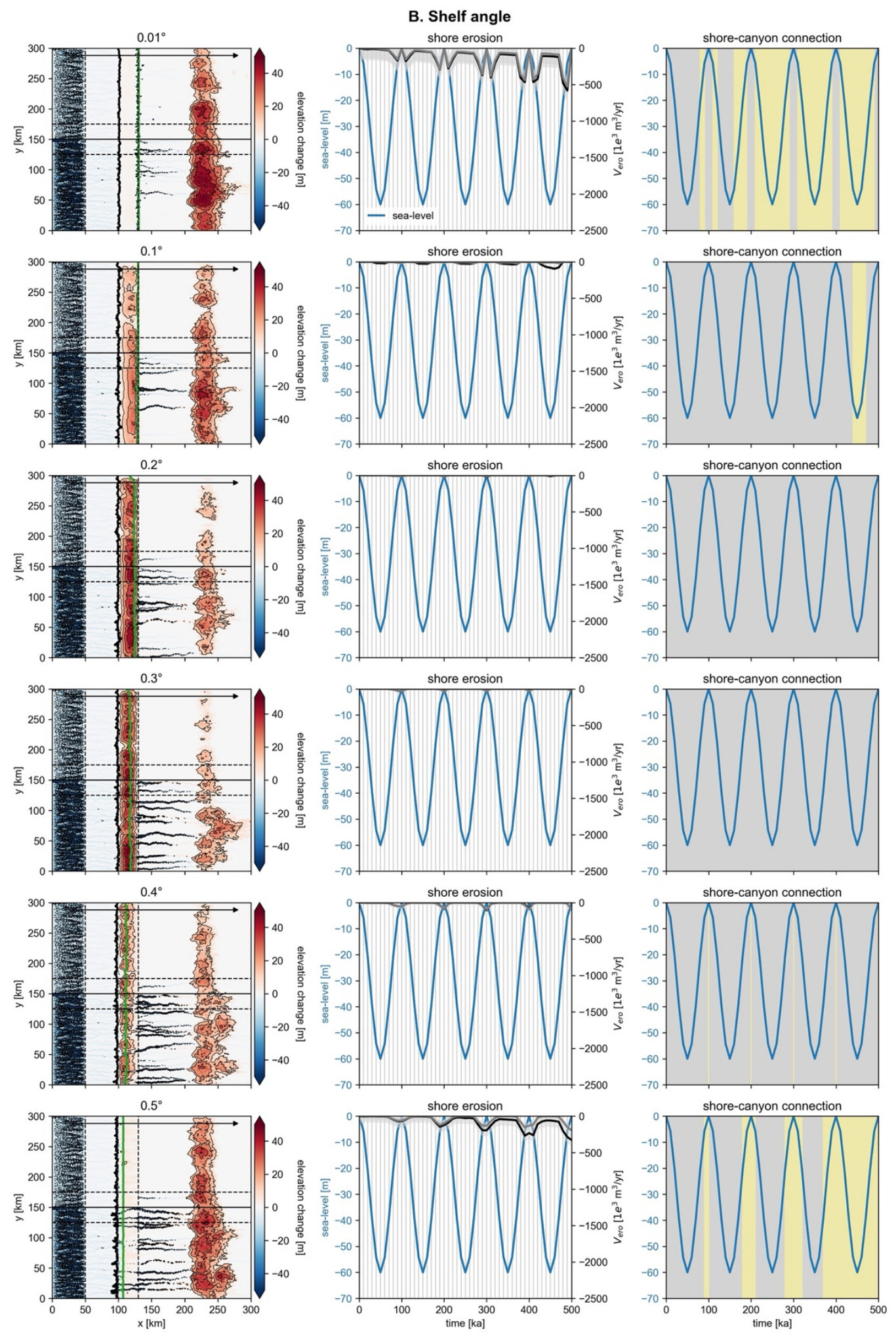


\section{Sea-level fall}
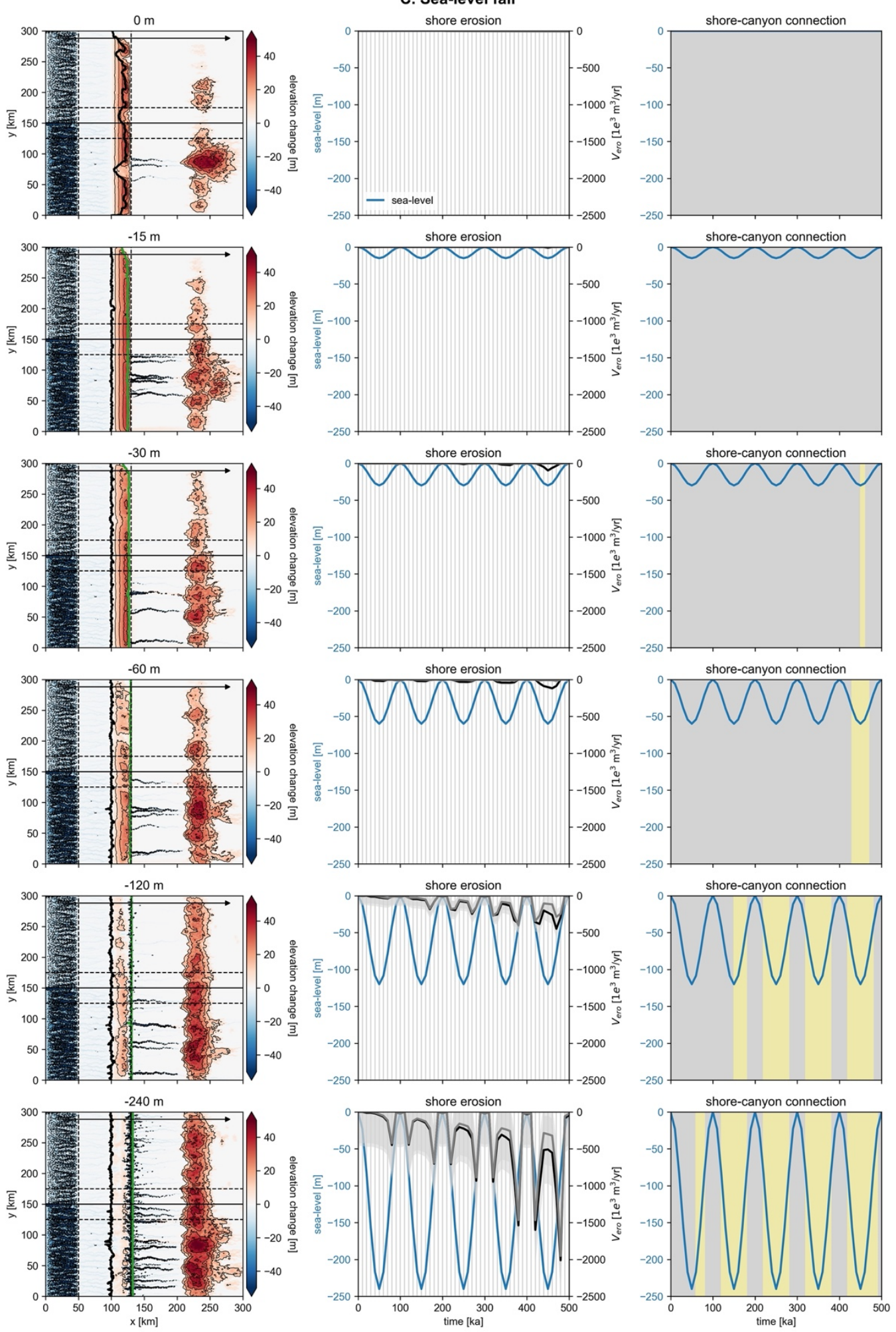

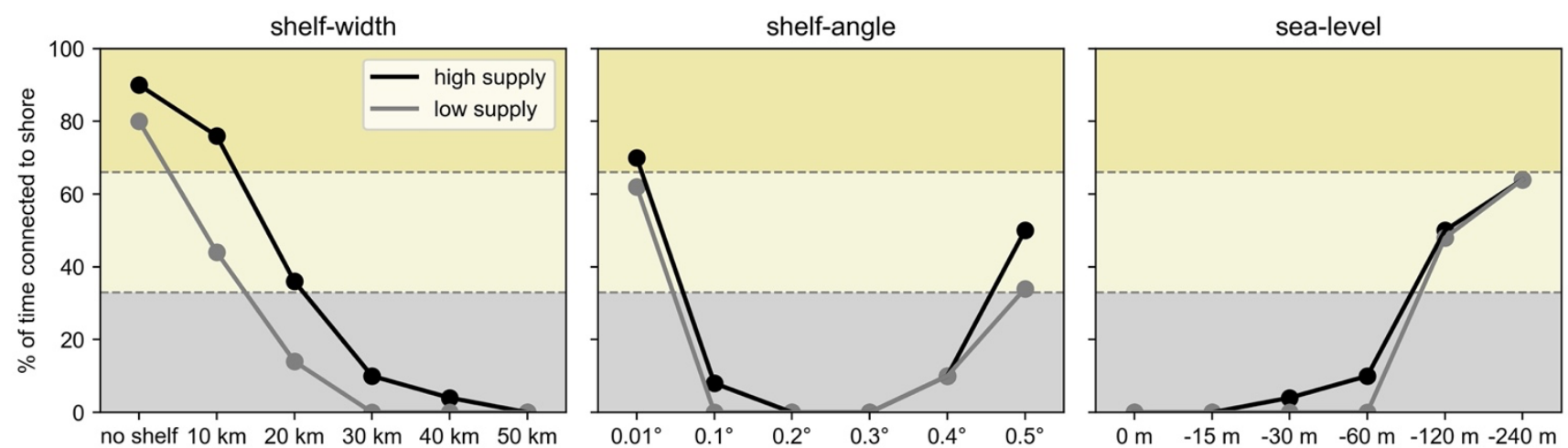

\section{Wider implications}

219 These findings have implications for predicting the prevalence of shore-connected canyons through time, with

220 submarine canyon incision fundamentally linked to the climate and physiography of the subaerial basin, the

221 physiography of the shelf, and sea-level magnitude, all of which are approximately related through:

$$
W_{S} \sim \frac{\Delta S L}{S}
$$

225 Where $W_{s}$ is the width of the shelf, $\Delta \mathrm{SL}$ is the magnitude of sea-level change, $S$ is the onshore river gradient (Sweet and 226 Blum, 2018). Shelf margin positions are typically set by low sea-levels (Blum et al. 2013; Sweet and Blum, 2018).

227 Therefore, on passive margins, low gradient rivers tend to produce wide shelves as rivers have to travel a further distance

228 to reach the shelf margin. Conversely, high-gradient rivers typically produce narrow shelves, as rivers have to travel less

229 distance to reach the shelf margin (Sweet and Blum, 2018). During periods of high-magnitude sea-level change, when

230 shore-connected submarine canyons are expected to be prevalent, shelves tend to be wider, which reduces the

231 likelihood of shore-connected canyons. This circular relationship forms a natural buffer on the prevalence of shore-

232 connected submarine canyons, and therefore the efficiency of sediment transfer to deep-water. Any submarine canyons 
233 that do form are only connected to the shoreline when sea-levels are low, resulting in punctuated coarse-grained supply

234 to deep-water observed on many passive continental margins (Blum et al. 2013), and areally-restricted deposition due

235 to reduced deltaic avulsion on incised shelves (Harris et al. 2020).

237 This circular relationship falls apart on active margins, where shelf widths are reduced by tectonically-elevated onshore

238 river gradients. On these margins submarine canyon incision will be magnified by the combined influence of high

239 sediment supplies, narrow shelves and high-magnitude sea-level changes, resulting in consistent connection of 240 submarine canyons to the shoreline, and the efficient transfer of terrigenous sediment to deeper-waters.

241 Stratigraphically, this would result in sustained delivery of coarse-grained sediment to submarine fans, with eustasy

242 relatively uncoupled from their stratigraphic evolution. Sediment supply variation, driven by onshore climate or

243 tectonics, would instead be the dominant allogenic processes driving periods of coarse- and fine-grained deposition in

244 these fans. This has been observed in the shore-connected Congo canyon system, which formed during western African

245 uplift in the Pliocene and has been maintained by gravity flows derived from the Congo River (Ferry et al. 2004), with

246 deposition in Congo submarine fan principally controlled by onshore climate, irrespective of eustasy (Picot et al. 2019).

247 The Congo example also indicates that shore-connected canyons can be maintained well after the environmental

248 conditions that led to their inception, as long as the location of the fluvial system feeding the canyon is maintained.

250 In the case where sediment supplies are consistently high, such as during sustained hinterland uplift, slope erosion and

251 submarine fan deposition will also be high (Fig. 3, 4, 5). This study suggests that this will result in rapid back-filling of

252 the submarine canyon, as increasing submarine fan relief on the basin floor and increased erosional confinement on

253 the slope prevent avulsion. Submarine canyons consistently connected to shorelines may therefore aggrade more 254 quickly than canyons periodically disconnected from shorelines. 
256 During greenhouse periods of earth history, characterised by lower-magnitude sea-level changes, shelf widths are

257 naturally narrowed by higher sea-levels (Sweet and Blum, 2018). Submarine canyon incision is therefore balanced by

258 the positive influence of narrow-shelves and the negative influence of lower-magnitude sea-level changes. On active

259 margins with elevated river gradients, the relative impact of narrowed shelves will therefore be reduced when compared

260 to icehouse climates, as the magnitudes of sea-level change are reduced. This indicates that shore-connected submarine

261 canyons will be most prevalent on active margins during periods of high-magnitude sea-level change, such as during

262 icehouse climates or periods of tectonically-induced relative-sea-level change, which is supported by the observed

263 prevalence of river-associated canyons on active margins in the present (Fig. 1; Harris and Whiteway, 2011).

265 We therefore speculate that the inception and maintenance of shore-connected submarine canyons on active margins

266 during icehouse climates may form an underappreciated component of the global carbon cycle, with shore-connected

267 canyons along these margins enhancing bypass and burial of organic matter in deep-water (Galy et al. 2007), thus

268 enhancing cooling, lowering sea-levels, and further increasing the likelihood of shore-connected canyon formation.

269 Periods of widespread subaerial uplift during icehouse periods may therefore amplify cooling much more than the

270 equivalent tectonic activity during greenhouse climates, increasing the stability of cool periods. 


\section{shore-connected canyon formation}

$t_{1}$ high sea-level

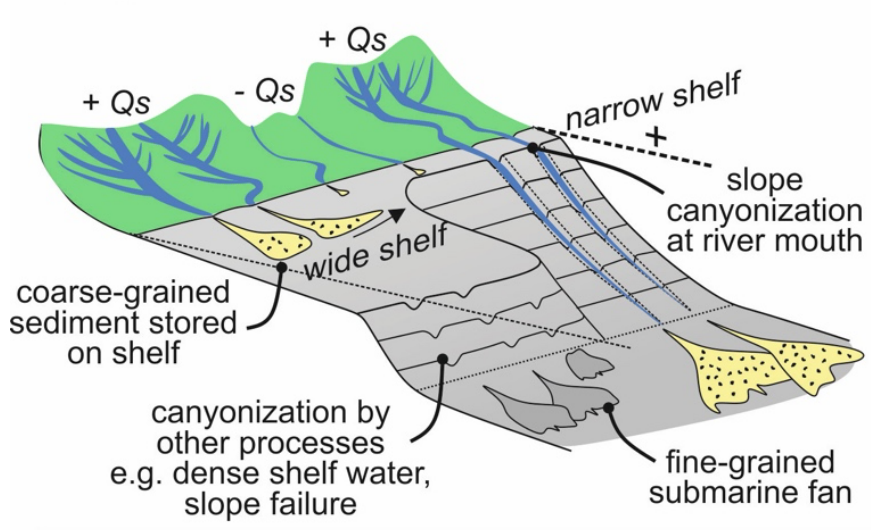

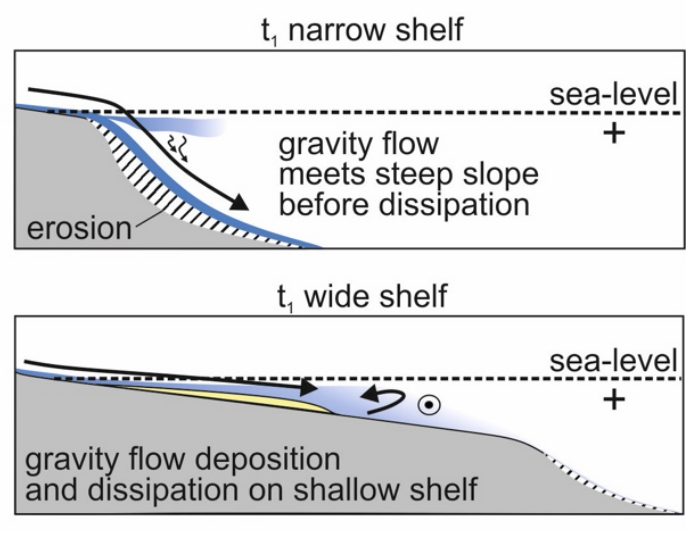

\section{$t_{2 \mathrm{~A}}$ if sea-level sustained gravity flows} captured by canyon relief increasing canyonization

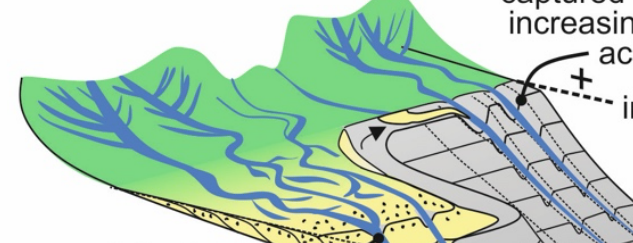

delta front and slope canyonization

submarine fan and apron
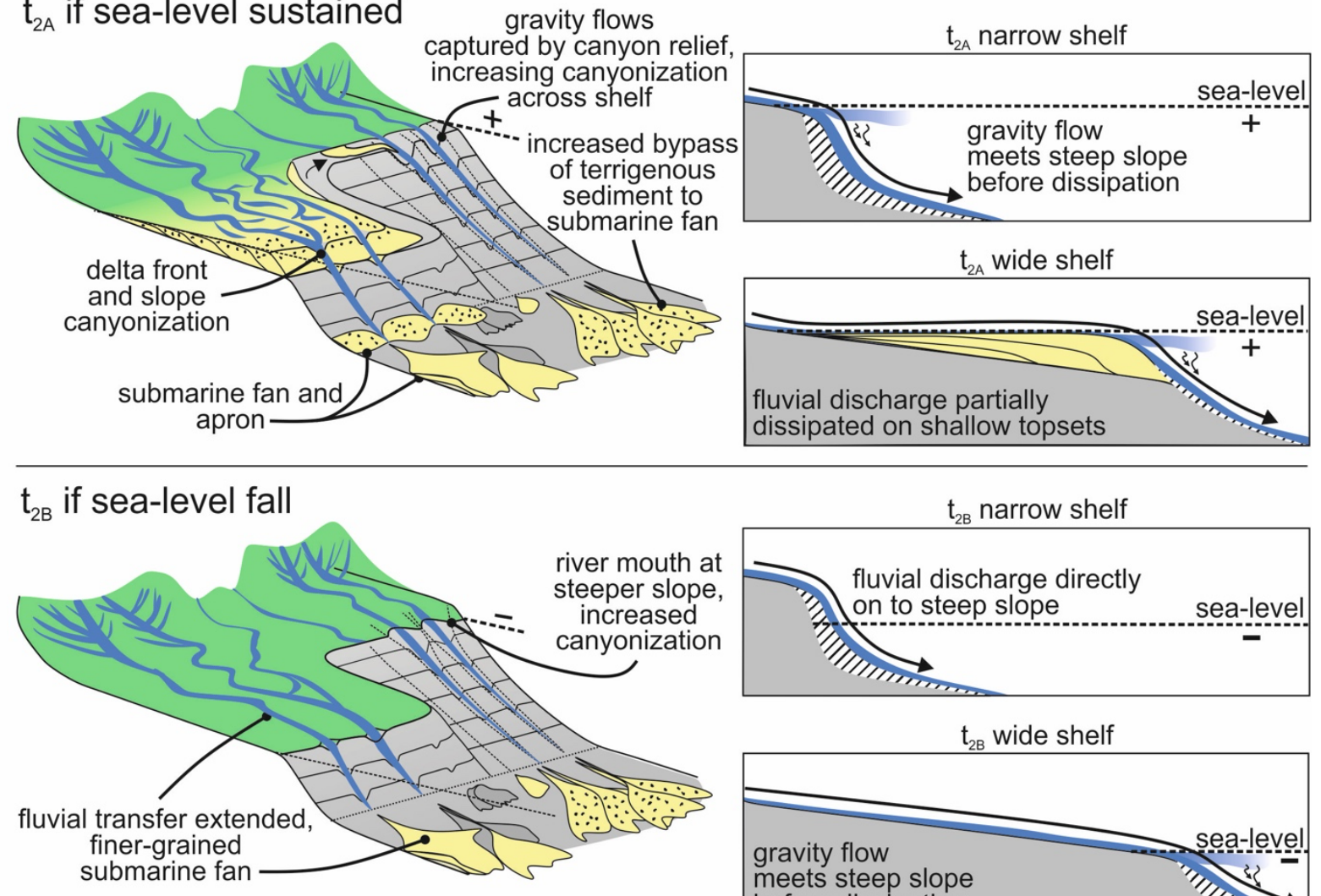

\section{5. Conclusion}

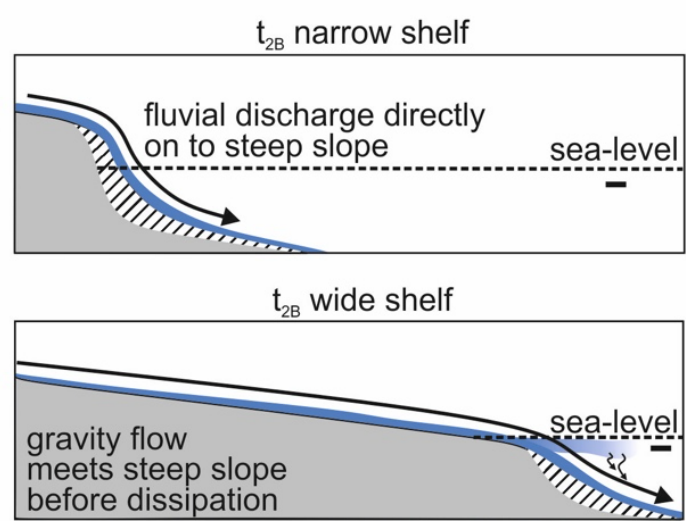

272 Shore-connected submarine canyons greatly enhance the potential for sediment bypass from shallow- to deep-water.

273 Numerical modelling has revealed that shore-connected canyons are most likely to form when fluvial discharge is high, 
274 the shelf is narrow and steep, and the magnitude of sea-level change is great, in agreement with modern observations.

275 This indicates that shore-connected canyon formation is fundamentally linked to quantifiable climatic and tectonic

276 factors, such as precipitation, tectonic uplift and sea-level fall. Periods of Earth history when sediment bypass to deep-

277 water was most efficient can therefore be estimated, with active margins during icehouse climates expected to be the

278 most efficient configurations for sediment export from shallow- to deep-water. Tectonism and enhanced subaerial

279 erosion may therefore have a much more pronounced impact on climate change during icehouse periods than

280 greenhouse periods. This will also be reflected in the stratigraphy of deep-marine successions, with eustasy having a

281 more muted influence than onshore climate and tectonics on active margins characterised by narrow and steep shelves.

\section{Data availability}

284 All code used for this study are open-source (https://badlands.readthedocs.io/en/latest/; Salles et al. 2018). Model

285 parameters in the supplementary files will reproduce these results, and an example XML input file from the $20 \mathrm{~km}$ wide

286 shelf simulation used is provided in the supplementary files.

\section{Acknowledgements}

289 The authors thank the Slope project Phase 5 sponsors for financial support: Aker BP, BHP, BP, CNOOC, Hess, 290 Murphy, Neptune Energy, Vår Energi, Wintershall DEA.

\section{References}

293 Allin, J.R., Hunt, J.E., Clare, M.A. and Talling, P.J., 2018, Eustatic sea-level controls on the flushing of a shelf-incising 294 submarine canyon: GSA Bulletin, v. 130, p. 222-237.

296 Athy, L.F., 1930, Density, Porosity and Compaction of Sedimentary Rocks. AAPG Bulletin, v. 14, p. 1-24. 
298 Beard, D.C. and Weyl, P.K., 1973, Influence of texture on porosity and permeability of unconsolidated sand: AAPG

299 Bulletin, v. 57, p. 349-369.

300

301 Bernhardt, A., and Schwanghart, W., 2021, Where and Why Do Submarine Canyons Remain Connected to the Shore

302 During Sea- level Rise? - Insights from Global Topographic Analysis and Bayesian Regression: Earth and Space Science

303 Open Archive, https://doi.org/10.1002/essoar.10505620.1.

305 Blum, M.D., Martin, J., Milliken, K., and Garvin, M., 2013, Paleovalley systems: insights from Quaternary analogs and 306 experiments: Earth-Science Reviews, v. 116, p. 128-169.

307

308 Braun, J. and Willett, S.D., 2013, A very efficient O (n), implicit and parallel method to solve the stream power equation 309 governing fluvial incision and landscape evolution: Geomorphology, v. 180, p. 170-179.

310 Buchanan, J. Y., 1887, On the land slopes separating continents and ocean basins, especially those on the West Coast

311 of Africa: Scottish Geographical Magazine, v. 3, p. 217-238.

312

313 Canals, M., Puig, P., de Madron, X.D., Heussner, S., Palanques, A. and Fabres, J., 2006. Flushing submarine canyons, 314 Nature, v. 444, p. 354-357.

315

316 Casalbore, D., Romagnoli, C., Bosman, A., Anzidei, M. and Chiocci, F.L., 2018, Coastal hazard due to submarine 317 canyons in active insular volcanoes: examples from Lipari Island (southern Tyrrhenian Sea): Journal of Coastal 318 Conservation, v. 22, p. 989-999.

320 Covault, J.A., Romans, B.W., Fildani, A., McGann, M. and Graham, S.A., 2010, Rapid climatic signal propagation from 321 source to sink in a southern California sediment-routing system: The Journal of Geology, v. 118, p. 247-259 
323 Covault, J.A. and Fildani, A., 2014, Continental shelves as sediment capacitors or conveyors: source-to-sink insights

324 from the tectonically active Oceanside shelf, southern California, USA: Geological Society, London, Memoirs, v. 41, p. $325315-326$.

327 Daly, R.A., 1936, Origin of submarine canyons: American Journal of Science, v. 31, p. 401-420.

329 Ding, X., Salles, T., Flament, N. and Rey, P., 2019, Quantitative stratigraphic analysis in a source-to-sink numerical 330 framework, Geoscientific Model Development, v. 12, p. 2571-2585.

332 Fagherazzi, S., Howard, A. D., \& Wiberg, P. L., 2004, Modeling fluvial erosion and deposition on continental shelves 333 during sea level cycles: Journal of Geophysical Research, v. 109, F03010.

\section{4}

335 Farre, J.A., McGregor, B.A., Ryan, W.B. and Robb, J.M., 1983, Breaching the shelfbreak: passage from youthful to 336 mature phase in submarine canyon evolution: SEPM Special Publication, v. 33, p. 25 - 39.

338 Ferry, J.N., Babonneau, N., Mulder, T., Parize, O. and Raillard, S., 2004, Morphogenesis of Congo submarine canyon 339 and valley: implications about the theories of the canyons formation: Geodinamica Acta, v. 17, p. 241-251.

341 Harris, A.D., Covault, J.A., Madof, A.S., Sun, T., Sylvester, Z. and Granjeon, D., 2016. Three-dimensional numerical 342 modeling of eustatic control on continental-margin sand distribution: Journal of Sedimentary Research, v. 86, p. 14343431443. 
345 Harris, A.D., Covault, J.A., Baumgardner, S., Sun, T. and Granjeon, D., 2020. Numerical modeling of icehouse and

346 greenhouse sea-level changes on a continental margin: Sea-level modulation of deltaic avulsion processes. Marine and

347 Petroleum Geology, 111, pp.807-814.

349 Harris, P.T. and Whiteway, T., 2011, Global distribution of large submarine canyons: Geomorphic differences between 350 active and passive continental margins: Marine Geology, v. 285, p. 69-86.

352 Harris, P.T., Macmillan-Lawler, M., Rupp, J. and Baker, E.K., 2014, Geomorphology of the oceans: Marine Geology, 353 v. 352, p. 4-24.

355 Huang, Z., Nichol, S.L., Harris, P.T. and Caley, M.J., 2014. Classification of submarine canyons of the Australian 356 continental margin: Marine Geology, v. 357, p. 362-383.

358 Khripounoff, A., Vangriesheim, A., Crassous, P. and Etoubleau, J., 2009, High frequency of sediment gravity flow 359 events in the Var submarine canyon (Mediterranean Sea): Marine Geology, v. 263, p. 1-6.

361 Lowe, D.R., 1976, Grain flow and grain flow deposits: Journal of Sedimentary Research, v. 46, p. 188-199.

363 Maier, K.L., Johnson, S.Y. and Hart, P., 2018, Controls on submarine canyon head evolution: Monterey Canyon, 364 offshore central California: Marine Geology, v. 404, p. 24-40.

366 Martin, Y., \& Church, M., 1997, Diffusion in landscape development models: On the nature of basic transport relations.

367 Earth Surface Processes and Landforms: The Journal of The British Geomorphological Group, v. 22, p. $273-279$. 
369 Melstrom, E.M. and Birgenheier, L.P., 2021, Stratigraphic architecture of climate influenced hyperpycnal mouth

370 bars. Sedimentology. In press.

372 Micallef, A., Mountjoy, J.J., Canals, M. and Lastras, G., 2012. Deep-seated bedrock landslides and submarine canyon

373 evolution in an active tectonic margin: Cook Strait, New Zealand., in Submarine mass movements and their

374 consequences: Springer, Dordrecht, p. $201-212$.

376 Miller, K.G., Browning, J.V., Schmelz, W.J., Kopp, R.E., Mountain, G.S. and Wright, J.D., 2020, Cenozoic sea-level 377 and cryospheric evolution from deep-sea geochemical and continental margin records: Science Advances, v. 6, 378 eaaz1346

379 Milliman, J.D. and Farnsworth, K.L., 2013, River discharge to the coastal ocean: a global synthesis: Cambridge 380 University Press. 382 p.

382 Mountjoy, J.J., Barnes, P.M. and Pettinga, J.R., 2009, Morphostructure and evolution of submarine canyons across an 383 active margin: Cook Strait sector of the Hikurangi Margin, New Zealand: Marine Geology, v. 260, p. 45-68.

384 Nienhuis, J.H., Ashton, A.D., Nardin, W., Fagherazzi, S. and Giosan, L., 2016, Alongshore sediment bypassing as a 385 control on river mouth morphodynamics: Journal of Geophysical Research: Earth Surface, v. 121, p. 664-683.

387 Nyberg, B., Helland-Hansen, W., Gawthorpe, R.L., Sandbakken, P., Eide, C.H., Sømme, T., Hadler-Jacobsen, F. and 388 Leiknes, S., 2018, Revisiting morphological relationships of modern source-to-sink segments as a first-order approach 389 to scale ancient sedimentary systems: Sedimentary Geology, v. 373, p. 111-133.

391 Petit, C., Migeon, S. and Coste, M., 2015, Numerical models of continental and submarine erosion: application to the northern Ligurian Margin (Southern Alps, France/Italy): Earth Surface Processes and Landforms, v. 40, p. 681-695. 
394 Picot, M., Marsset, T., Droz, L., Dennielou, B., Baudin, F., Hermoso, M., De Rafélis, M., Sionneau, T., Cremer, M.,

395 Laurent, D. and Bez, M., 2019, Monsoon control on channel avulsions in the Late Quaternary Congo Fan: Quaternary

396 Science Reviews, v. 204, p. 149-171.

397

398 Pratson, L.F. and Coakley, B.J., 1996, A model for the headward erosion of submarine canyons induced by downslope-

399 eroding sediment flows: GSA Bulletin, v. 108, p. 225-234.

400

401 Pratson, L.F., Ryan, W.B., Mountain, G.S. and Twichell, D.C., 1994, Submarine canyon initiation by downslope-eroding

402 sediment flows: evidence in late Cenozoic strata on the New Jersey continental slope: GSA Bulletin, v. 106, p. 395-412. 403

404 Puig, P., Palanques, A., Orange, D.L., Lastras, G. and Canals, M., 2008, Dense shelf water cascades and sedimentary 405 furrow formation in the Cap de Creus Canyon, northwestern Mediterranean Sea: Continental Shelf Research, v. 28, p. $406 \quad 2017-2030$

407

408 Puig, P., Palanques, A. and Martín, J., 2014: Contemporary sediment-transport processes in submarine canyons. Annual 409 Review of Marine Science, v. 6, p. 53-77.

410

411 Raymo, M.E. and Ruddiman, W.F., 1992. Tectonic forcing of late Cenozoic climate: Nature, v. 359, p. 117-122.

412

413 Salles, T., Ding, X. and Brocard, G., 2018, pyBadlands: A framework to simulate sediment transport, landscape

414 dynamics and basin stratigraphic evolution through space and time: PloS one, v. 13, p. e0195557. 
416 Shepard, F.P., 1981, Submarine canyons: multiple causes and long-time persistence: AAPG bulletin, v. 65(6), p. 1062-

$417 \quad 1077$

418

419 Smith, M.E., Finnegan, N.J., Mueller, E.R. and Best, R.J., 2017, Durable terrestrial bedrock predicts submarine canyon

420 formation: Geophysical Research Letters, v. 44, p. 10-332.

421

422 Smith, M.E., Werner, S.H., Buscombe, D., Finnegan, N.J., Sumner, E.J. and Mueller, E.R., 2018. Seeking the shore:

423 Evidence for active submarine canyon head incision due to coarse sediment supply and focusing of wave

424 energy. Geophysical Research Letters, 45(22), pp.12-403.

425

426 Steel, E., Simms, A.R., Warrick, J. and Yokoyama, Y., 2016. Highstand shelf fans: The role of buoyancy reversal in the

427 deposition of a new type of shelf sand body. GSA Bulletin, 128(11-12), pp.1717-1724.

428

429 Sweeney, K.E., Roering, J.J. and Ellis, C., 2015, Experimental evidence for hillslope control of landscape scale: Science, 430 v. 349, p. 51-53.

431

432 Sweet, M.L. and Blum, M.D., 2016, Connections between fluvial to shallow marine environments and submarine

433 canyons: implications for sediment transfer to deep water: Journal of Sedimentary Research, v. 86, p. 1147-1162.

434

435 Thran, A.C., East, M., Webster, J.M., Salles, T. and Petit, C., 2020, The Influence of Carbonate Platforms on the

436 Geomorphological Development of a Mixed Carbonate-Siliciclastic Margin (Great Barrier Reef, Australia):

437 Geochemistry, Geophysics, Geosystems, v. 21, p. e2020GC008915. 
439 Whipple, K.X. and Tucker, G.E., 1999, Dynamics of the stream-power river incision model: Implications for height

440 limits of mountain ranges, landscape response timescales, and research needs: Journal of Geophysical Research: Solid

441 Earth, v. 104, p. 17661-17674.

442

443 Zhang, J., Sylvester, Z., Covault, J., 2020, How do basin margins record long-term tectonic and climatic changes?:

444 Geology ; v. 48, p. 893-897

\section{Figures}

447 Figure 1: A) Example of a shore-connected canyon that has incised across the shelf, offshore Chile (source:

448 GeoMapApp $\left.{ }^{(}\right)$. The canyon was able to incise across the shelf during recent sea-level rise as it is associated with a

449 major river. B) Number of river-associated canyons in each geographic region at the present-day. The geographic

450 region is coloured by whether it is tectonically-passive or tectonically-active margin (data from Harris and Whiteway

451 2011).

453 Figure 2: A) Planform configuration of the model grid. B) Dip configuration of the model grid. Steeper source $(+)$ is

454 the higher supply lower segment of the grid, shallower source (-) is the lower supply upper segment of the grid. Solid

455 black lines represent the shelf-width variations, and dashed black lines represent the shelf angle variations. C) Sea-level 456 curves used in these simulations. A - $60 \mathrm{~m}$ curve is used for all of the shelf variations.

458 Figure 3: A) Planform elevation maps at the end of the models with no shelf to a $50 \mathrm{~km}$ wide shelf. Red indicates 459 deposition, blue indicates erosion. B) Volume of eroded sediment in the coastal zone erosion and sea-level change 460 through time. Grey shade is one standard deviation of all values, and grey vertical lines are modelled time-steps. For 461 ease of comparison the y-axis is scaled to the maximum eroded volume seen across all models in this study. 462 
463 Figure 4: A) Planform elevation maps at the end of the models with a $0.01^{\circ}$ to a $0.5^{\circ}$ dipping shelf. Red indicates

464 deposition, blue indicates erosion. B) Volume of eroded sediment in the coastal zone erosion and sea-level change

465 through time. Grey shade is one standard deviation of all values, and grey vertical lines are modelled time-steps. For

466 ease of comparison the y-axis is scaled to the maximum eroded volume seen across all models in this study.

468 Figure 5: A) Planform elevation maps at the end of the models with no sea-level fall to a $240 \mathrm{~m}$ sea-level fall.

469 Red indicates deposition, blue indicates erosion. B) Volume of eroded sediment in the coastal zone erosion and sea-

470 level change through time. Grey shade is one standard deviation of all values, and grey vertical lines are modelled

471 time-steps. For ease of comparison the y-axis is scaled to the maximum eroded volume seen across all models in this

472 study.

474 Figure 6: Percentage of time canyons are connected to the shore on the high-supply and low-supply sides of the each

475 numerical model.

477 Figure 7: Model for the formation of shore-connected submarine canyons along a continental margin with variable

478 sediment supply and a variable shelf width. The model begins with initial highstand deposition ( $\mathrm{t}_{1}$ ) before following

479 two separate futures; one where the sea-level is sustained at highstand $\left(\mathrm{t}_{2 \mathrm{~A}}\right)$, and one where the sea-level falls to a

480 lowstand $\left(\mathrm{t}_{2 \mathrm{~B}}\right)$.

482 Supplementary information

483

484 Supplementary Table 1: Parameters used for each of the model iterations. 
486 Supplementary Figure 1: Relationship between the parameters varied in this study. A. shelf width and average shelf 487 gradient, B. shelf width and average slope gradient, and C. average shelf gradient and average slope gradient from 488 modern systems (data from Nyberg et al. 2018). Relationship between the parameters varied in this study. A) shelf 489 width and average shelf gradient, B) shelf width and average slope gradient, and C) average shelf gradient and average 490 slope gradient from modern systems (data from Nyberg et al. 2018; randomly sub-sampled to 1000 points). 

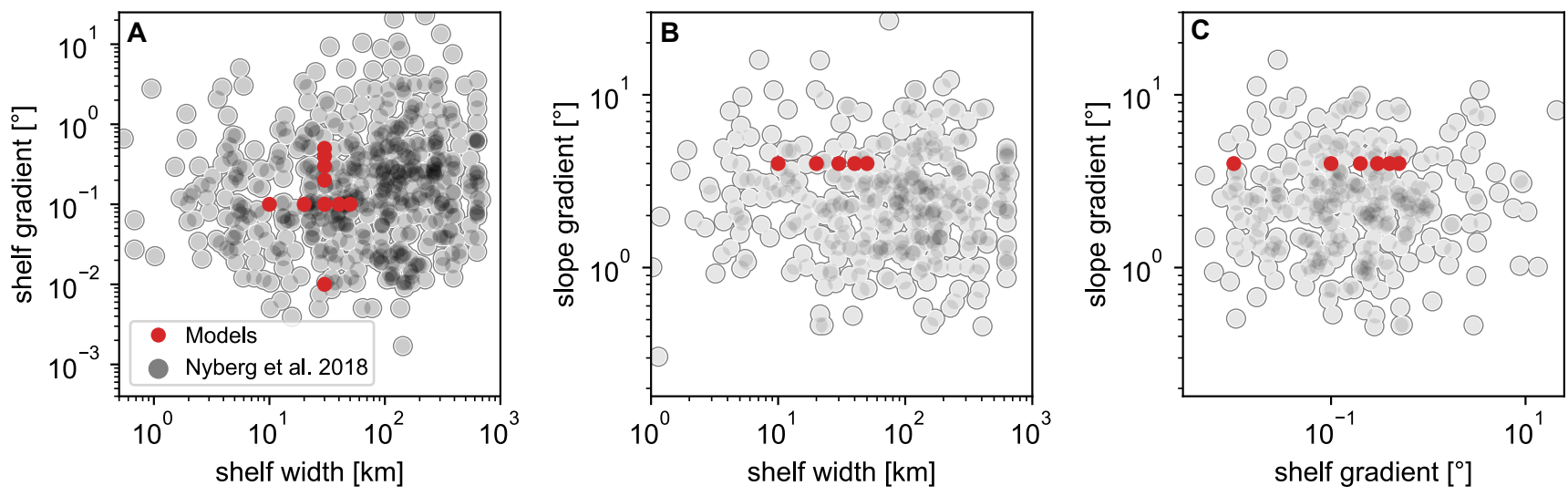